\title{
The development of Myxobolus pavlovskii (Myxozoa: Myxobolidae) includes an echinactinomyxon-type actinospore
}

\author{
Szilvia Marton and Edit Eszterbauer
}

Veterinary Medical Research Institute, Hungarian Academy of Sciences, P.O. Box 18, H-1581 Budapest, Hungary

\begin{abstract}
Echinactinomyxon-type actinospores were found in a mixed-species oligochaete culture originating from the Temperate Water Fish Hatchery near Budapest, Hungary. On the basis of DNA sequence analysis, the actinospores were identified as Myxobolus pavlovskii (Akhmerov, 1954), the 18S rDNA sequence from myxospores of which is available in GenBank. Silver carp Hypophthalmichthys molitrix (Valenciennes) fry specimens were successfully infected by cohabitation with the echinactinomyxon-releasing oligochaetes, which confirmed the molecular data congruence. The echinactinomyxons and the myxospores that developed in the gills of exposed fish fry were analysed morphologically and on DNA basis. The infected gill tissue was examined histologically. As typical characters of M. pavlovskii, numerous small plasmodia were observed in the epithelia of gill lamellae. Plasmodia contained thousands of myxospores with polar capsules unequal in size and with large intercapsular processes. The 18S rDNA sequence from actinospores and those from myxospores originating from the experimentally infected fish were identical. The oligochaete species releasing actinospores was morphologically determined as Limnodrilus sp. This is the first record of an echinactinomyxon as an alternate stage within the genus Myxobolus.
\end{abstract}

Keywords: Myxosporea, life cycle, silver carp, Hypophthalmichthys molitrix, 18S rDNA, histology, infection experiment

Myxobolus pavlovskii (Akhmerov, 1954) is a myxozoan parasite of the silver carp Hypophthalmichthys molitrix (Valenciennes) and the bighead carp Hypophthalmichthys nobilis (Richardson). These two fish species were introduced to Hungary from Eastern Asia (China and the former USSR) in the early 1960s. The fish populations in China already had been infected with M. pavlovskii, and after the introduction to Hungary in the course of a breeding programme of herbivorous fish, the parasite was disseminated throughout the country (Molnár 1979). Myxobolus pavlovskii infects the gills and develops in the stratified epithelium between gill lamellae, where the developing plasmodia can fill the interlamellar space (Molnár 2002). In heavy infections, it may cause severe pathological changes by hampering the host gas exchange and excretion.

Molnár (1979) was the first to conduct infection experiments with this parasite to obtain further information on its development. He examined several specimens of silver carp and bighead carp from three fish farms in Hungary for the presence of $M$. pavlovskii, and performed both field and laboratory experiments. In the field, he could not prevent uncontrolled infection of parasite-free fry despite a variety of pre-treatments (e.g., desiccation of the pond, mud removal, quicklime treatment). Successful laboratory infections of fish were only possible using mud/soil as a source of the infectious agent (Molnár 1979). Later, Ruidish et al. (1991) performed transmission experiments in order to elucidate the life cycle of $M$. pavlovskii in greater detail. Myxospores originating from naturally infected silver carp, identified as M. pavlovskii by morphological measurements, were used for the infection of oligochaetes. Tubificid oligochaetes were added to the aquaria containing myxospores, and after 93 days post exposure (p.e.), hexactinomyxon-type actinospores were detected in the water. By cohabitation of infected oligochaetes and silver carp, one-year-old fish specimens became infected. After 120 days p.e., cysts containing myxospores were found between the lamellae of gills. In the study by these authors, only morphological characters were used to identify the spores.

The present study was initiated after echinactinomyxon-type actinospores had been observed in a mixed oligochaete culture collected in the Temperate Water Fish Hatchery (TEHAG) near Budapest, Hungary. The 18S rDNA sequence of these actinospores had been found identical with that of $M$. pavlovskii myxospore isolates previously studied by Eszterbauer (2004). This finding contradicted the results obtained by Ruidish et al. (1991) and suggested that an echinactinomyxon instead of a hexactinomyxon might be the actinospore stage of $M$. pavlovskii. 
Among other gill-parasitic Myxobolus species, Eszterbauer et al. (2002) studied M. pavlovskii from silver carp and bighead carp on a molecular basis using PCR-RFLP (restriction fragment length polymorphism). They found the same restriction pattern with three restriction enzymes and demonstrated that M. pavlovskii is able to infect both fish hosts. In another study by Eszterbauer (2004), phylogenetic analyses of gill-infecting Myxobolus species confirmed that the myxospores morphologically identified as $M$. pavlovskii are indeed identical in silver carp and bighead carp. In the present study, transmission experiments, morphological and histological methods as well as molecular biological techniques were used to complete the characterisation of M. pavlovskii and clarify its controversial life cycle.

\section{MATERIALS AND METHODS}

\section{Collection and examination of actinospores}

Mud samples containing oligochaetes were collected from the Temperate Water Fish Hatchery (TEHAG) located at Százhalombatta near Budapest, Hungary. Mud and sediments were sifted in the laboratory to collect large oligochaetes (i.e. tubificids). The worms were kept in aerated 25-litre plastic tanks containing a layer of autoclaved mud with sand and were fed a mixture of minced frozen lettuce, Spirulina powder (MaBitec), and frozen Artemia or bloodworms once a week. Water changes were carried out weekly. To check for myxozoan infection, water from the cultures was regularly filtered through $20 \mu \mathrm{m}$ nylon mesh, and the presence of actinospores was checked with a Zeiss Axiostar Plus phase contrast microscope. In order to identify the infection of oligochaete specimens, approximately 300 worms were sampled from the culture and the individual worms were placed in cell-well plates as described by Yokoyama et al. (1991). After $24 \mathrm{hrs}$, the water in the wells was examined for the presence of released actinospores. Photomicrographs of actinospores were taken using a Moticam 2000 (Motic) digital camera mounted on a Zeiss Axiostar Plus microscope. Measurements were taken using Motic Images Plus 2.0 software after calibration. Actinospores were collected for molecular biological identification in $1.5-\mathrm{ml}$ microtubes and stored at $-20^{\circ} \mathrm{C}$ until further use. The species composition of the oligochaete culture was examined morphologically as well as with the use of molecular markers.

\section{Experimental infections}

For the infection trial, eight parasite-free silver carp ( $H y$ pophthalmichthys molitrix) fry specimens ( $3-4 \mathrm{~cm}$ total length) were used that had been reared from fertilized spawn. They were kept in the laboratory under parasite-free conditions and fed with Perla Larva Proactive (Skretting) and frozen lobster eggs (van Gerven). The fish were infected with actinospores by a twoweek cohabitation with the spore-releasing oligochaete culture before they were placed in a 30-litre aquarium. After 94 days, the fish were dissected, and the gills were examined for the presence of myxospores. Detected plasmodia were isolated from gill tissues and myxospores were collected for morphological and molecular identification. Photomicrographs were taken of the infected gill filaments, and gills were fixed for histological examination. Whole gill arches were fixed in $10 \%$ neutral buffered formalin, embedded in paraffin, cut approximately in $5 \mu \mathrm{m}$ thin sections, and stained with haematoxylin and eosin.

Myxospores collected from the gills of five silver carp specimens infected experimentally in the present study were used to infect oligochaetes. The M. pavlovskii cysts were scraped off the gill filaments with a dissecting needle and ruptured. The obtained spore suspension was homogenized by vortexing and the number of myxospores was estimated in a Bürker-chamber. The oligochaete culture used in the infection trial contained various Tubifex tubifex lineages and Limnodrilus spp. The worm stock originated from the Temperate Water Fish Hatchery (TEHAG) located in Százhalombatta near Budapest, Hungary, as well as from a small stream devoid of fish located near Aufseß, Germany. Prior to infection trial, the worm stock was kept under laboratory conditions for over a year, during which time it was periodically checked for the presence of waterborne actinospores, with negative results. This worm stock also served as a negative control in the infection trial. Approximately $10 \mathrm{~g}$ of oligochaetes were placed into a 5-litre aerated plastic tank containing water and a $2-\mathrm{cm}$ thick layer of mixed mud and sand. For exposure, M. pavlovskii myxospores $\left(>10^{6}\right)$ were added to the worm cultures. After one month p.e., the water from the exposed cultures and the control was regularly checked for the presence of actinospores by filtration for a period of 6 months.

\section{Molecular biological analysis}

Myxospore and actinospore samples and one infected oligochaete specimen were brought to molecular identification. For DNA extraction, the samples were centrifuged at 7,000 $\times g$ for $5 \mathrm{~min}$, spores were suspended in $500 \mu \mathrm{l}$ lysis buffer $(100 \mathrm{mM}$ $\mathrm{NaCl}, 10 \mathrm{mM}$ Tris, $10 \mathrm{mM}$ EDTA, $0.2 \%$ sodium dodecyl sulphate and $0.4 \mathrm{mg} / \mathrm{ml}$ proteinase $\mathrm{K}$ ) and incubated at $55^{\circ} \mathrm{C}$ for 3-4 hrs. DNA was purified using a Miniprep Express Matrix (BIO 101, Qbiogene) as described by Eszterbauer (2004). A nested PCR assay was applied for the amplification of the $18 \mathrm{~S}$ rDNA from the myxospores and actinospores. In the first round, primers 18e (5'-CTG GTT GAT TCT GCC AGT-3') (Hillis and Dixon 1991) and 18r (5'-CTA CGG AAA CCT TGT TAC-3') (Whipps et al. 2003) were used, followed by a second round PCR with the primer pair SphF (5'-ACT CGT TGG TAA GGT AGT GGC T-3') - SphR (5'-GTT ACC ATT GTA GCG CGC GT-3') (Eszterbauer and Székely 2004). For both steps of the nested PCR, the reaction volume was $50 \mu$, which contained up to $150 \mathrm{ng}$ DNA, $1 \times$ Taq PCR reaction buffer (MBI Fermentas), $1.25 \mathrm{mM} \mathrm{MgCl}, 0.2 \mathrm{mM}$ dNTP mix (Sigma), $50 \mu \mathrm{M}$ of each primer and 2 units of Taq DNA Polymerase (MBI Fermentas). The conditions were: a denaturation step of $5 \mathrm{~min}$ at $95^{\circ} \mathrm{C}$, followed by 35 cycles at $95^{\circ} \mathrm{C}$ for $50 \mathrm{sec}, 59^{\circ} \mathrm{C}$ for $50 \mathrm{sec}, 72^{\circ} \mathrm{C}$ for $80 \mathrm{sec}$, and a final extension step of $5 \mathrm{~min}$ at $72^{\circ} \mathrm{C}$. To amplify the entire sequence of the $18 \mathrm{~S}$ rDNA, the primer combinations ERI-B1 (5'-ACC TGG TTG ATC CTG CCA G-3') (Barta et al. 1997) - MB3 (5'-CCA ACC GCT CCT GTT AAT CAT C-3') (Molnár et al. 2002) and Myx4rF (5'-GTT CGT GGA GTG ATC TGT CAG-3') (the reverse complement of Myx4r by Hallett and Diamant 2001) - ERIB-10 (5'-CTT CCG CAG GTT CAC CTA CGG-3') (Barta et al. 1997) were used additionally. For identification of oligochaetes, an approximately $370 \mathrm{bp}$ fragment of the mitochondrial $16 \mathrm{~S}$ rDNA was amplified using the primer pair Tub16SF (5'-AAC GGC CGC GGT ATC CTG3') and Tub16SR (5'-TAA RCC AAC ATY GAG GTG CCA-3') 
(Beauchamp et al. 2001). The amplification conditions were as described above.

A Biometra T1 thermocycler (Whatman Biometra) was used for PCR amplification. The products were electrophoresed in $1 \%$ agarose gels with TAE buffer. The amplicons were purified either directly or from the agarose gel using a MEGAquick-Spin PCR and Agarose Gel DNA Extraction System (iNtRON Biotechnology). The PCR products were sequenced in both directions using the primers ERI-B1, ERI-B10 (Barta et al. 1997), ACT1f, ACT1fr (Hallett and Diamant 2001), MB5, MC3 (Molnár et al. 2002), and MYX4rF. Sequencing reactions were prepared with the ABI BigDye Terminator v3.1 Cycle Sequencing Kit (Applied Biosystems). Chromatograms were obtained using an ABI Prism 3100 Genetic Analyzer capillary sequencer. For sequence assembling, the STADEN Sequence Analysis Package, Version 4.1 (Staden 1996) was applied. DNA sequence similarities were calculated with the Sequence Identity Matrix of BioEdit (Hall 1999).

\section{RESULTS}

From the approximately 300 oligochaete specimens originating from TEHAG and individually examined in cell-well plates, only two released echinactinomyxontype actinospores (Fig. 1). No other water-borne actinospores were detected either in the wells or in the rest of the worm culture. As one worm specimen of the two died due to the microscopical examination, only one infected worm could be further used. Morphological examination revealed that the specimen at hand was a Limnodrilus sp., as it did not possess hair chaetae. However, the worm could not be identified more precisely because it was immature.

The measurements of the echinactinomyxon-type actinospores released by the two oligochaetes are presented in Table 1. The sporoplasms of the actinospores contained $32(30-34)$ secondary cells $(n=6)$. Polar capsules were

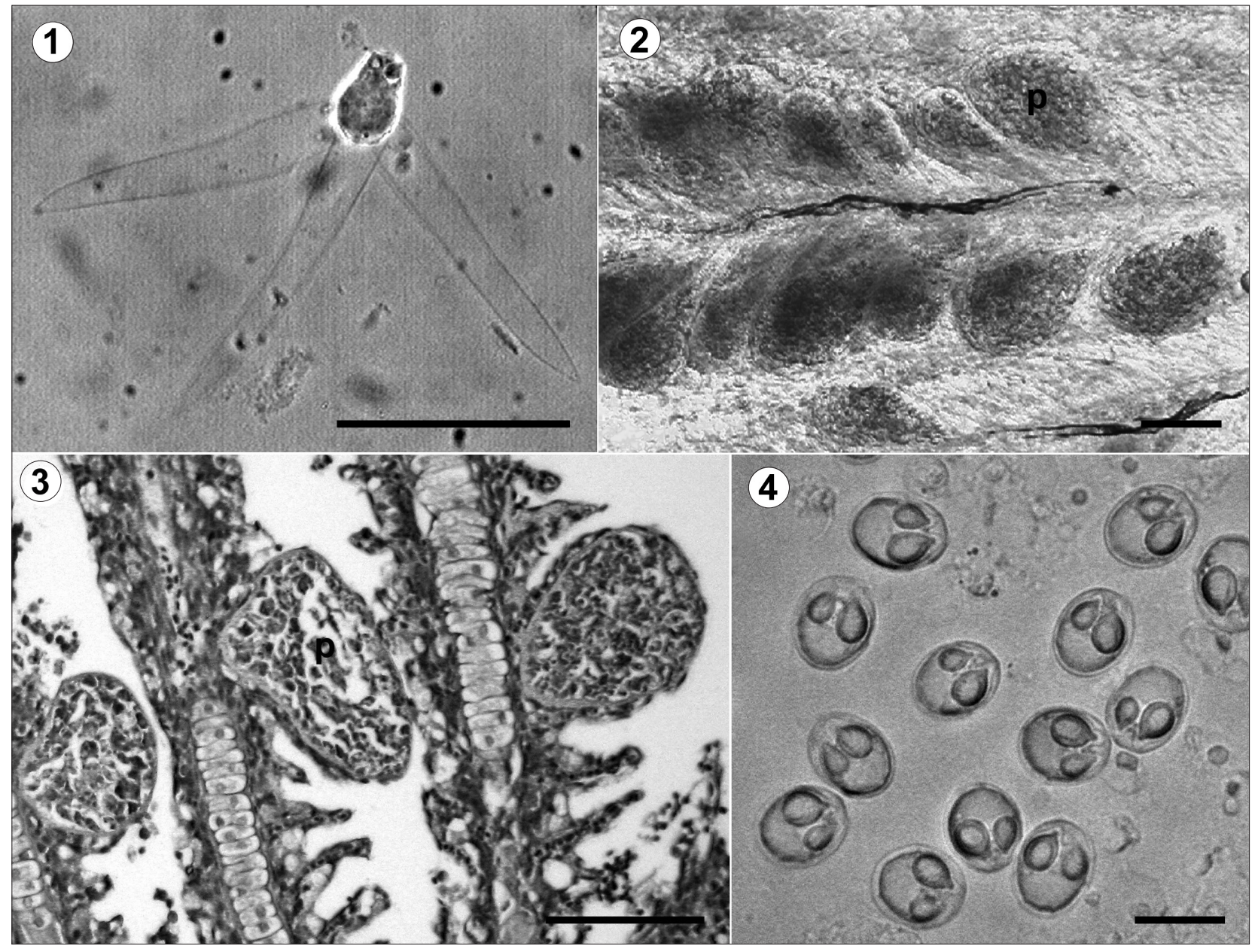

Figs. 1-4. Myxobolus pavlovskii and its infection in the silver carp Hypophthalmichthys molitrix. Fig. 1. Echinactinomyxon-type actinospore of M. pavlovskii released by Limnodrilus sp.; native preparation. Fig. 2. Massive infection with M. pavlovskii in the gill filaments of a silver carp; plasmodia (p) containing several hundred myxospores develop in the epithelium of gill lamellae; native preparation. Fig. 3. Histological section of the infected gill filament with M. pavlovskii plasmodia (p) located in the epithelium of gill lamellae; H\&E. Fig. 4. Myxospores of M. pavlovskii from an experimentally infected silver carp; native preparation. Scale bars: Figs. $1,3=50 \mu \mathrm{m}$; Fig. $2=100 \mu \mathrm{m}$; Fig. $4=10 \mu \mathrm{m}$. 
Table 1. Measurements of Myxobolus pavlovskii actinospores $(n=16)$ and of the most similar echinactinomyxon-type actinospores described previously (the mean with the range in parentheses; in $\mu \mathrm{m}$ ).

\begin{tabular}{llllll}
\hline Type/species & Authority & $\begin{array}{l}\text { Spore body } \\
\text { length; width }\end{array}$ & $\begin{array}{l}\text { Caudal process } \\
\text { length; width }\end{array}$ & SC & IH \\
\hline Echinactinomyxon & present study & $15.2(12.4-19) ; 12.1(10-14.6)$ & $80.26(70.5-88.9) ; 7.6(5.8-11.0)$ & 32 & L. sp. \\
E. radiatum & Janiszewska 1957 & L: $25-30$ & L: $100-125$ & 32 & T.t. \\
E. radiatum-like & Xiao and Desser 1998 & S: $25(23-26) ; 16.5(15.5-18)$ & $90(80-95) ; 7.5(7-8)$ & $16 / 32$ & T.t. \\
Echinactinomyxon 'C' & Xiao and Desser 1998 & $13(12-14) ; 10(8.5-12)$ & $83(70-95) ; 5.5(5-6)$ & 16 & L.h. \\
Echinactinomyxon 'D' & Xiao and Desser 1998 & $16(15-17) ; 11.5(11-12.5)$ & $100(85-105) ; 6-7$ & $16 / 32$ & L.h. \\
Echinactinomyxon 'type 2' & Negredo and Mulcahy 2001 $19.6(18.2-20.8) ; 13(13-13)$ & $82.2(74.1-91) ; 8.4(7.8-10.4)$ & 25 & Lum. v. \\
\hline
\end{tabular}

$\mathrm{SC}$ - number of the secondary cells; IH - invertebrate host; L - length; S - sporoplasm; L. sp. - Limnodrilus sp.; T. t. - Tubifex tubifex; L. h.- Limnodrilus hoffmeisteri; Lum. v. - Lumbriculus variegatus.

Table 2. Measurements of Myxobolus pavlovskii myxospores from the present study and of those described by Akhmerov (1954) (mean \pm SD with the range in parentheses; in $\mu \mathrm{m}$ ).

\begin{tabular}{|c|c|c|c|c|c|c|c|}
\hline & \multicolumn{3}{|c|}{ Spore } & \multicolumn{2}{|c|}{ Large polar capsule } & \multicolumn{2}{|c|}{ Small polar capsule } \\
\hline & length & width & thickness & length & width & length & width \\
\hline Present study $(n=41)$ & $\begin{array}{c}10.0 \pm 0.92 \\
(7.8-11.9)\end{array}$ & $\begin{array}{c}8.4 \pm 0.56 \\
(7.3-9.4)\end{array}$ & $\begin{array}{c}6.35 \pm 0.36 \\
(5.8-6.8)\end{array}$ & $\begin{array}{c}4.2 \pm 0.53 \\
(3.4-5.6)\end{array}$ & $\begin{array}{c}3.3 \pm 0.51 \\
(2.6-4.5)\end{array}$ & $\begin{array}{c}2.8 \pm 0.30 \\
(2.3-3.4)\end{array}$ & $\begin{array}{c}2.3 \pm 0.30 \\
(1.9-3.1)\end{array}$ \\
\hline Akhmerov 1954 & $8.5-10$ & $9.1-10$ & $6-7$ & 5-6 & $2.5-4.2$ & $3-4$ & $2.5-3$ \\
\hline
\end{tabular}

located anteriorly, deep beneath the valve. From these echinactinomyxons, an approximately 1,400-bp-long $18 \mathrm{~S}$ rDNA fragment was successfully amplified by the nested PCR assay using the $18 \mathrm{e}-18 \mathrm{r}$ and SphF-SphR primer pairs. The sequence of this part of the $18 \mathrm{~S}$ rDNA suggested that this echinactinomyxon was the actinospore stage of $M$. pavlovskii. The entire consensus sequence of the 18S rDNA was 2,004-bp-long (GenBank Acc. No. HM991164), and shared a $99.87 \%$ similarity with the 1,578-bp-long, partial 18S rDNA sequence of M. pavlovskii available in GenBank (AF507973). According to BLASTn search results, Myxobolus musseliusae (GenBank Acc. No. FJ710801), a gill parasite of common carp, was the most similar species to M. pavlovskii $(91.79 \%$ DNA sequence similarity).

The oligochaete laboratory culture was composed of Tubifex tubifex (Müller) lineages II and V (as classified by Beauchamp et al. 2001), Limnodrilus species such as L. hoffmeisteri Claparède, L. udekemianus Claparède, as well as Psammoryctides barbatus (Grube). From one echinactinomyxon-releasing worm, a 335-bp-long sequence of the mitochondrial 16S rDNA was successfully amplified (GenBank Acc. No. HM991165). A BLASTn search revealed a $95.59 \%$ sequence similarity to L. udekemianus (GenBank Acc. No. AF325986).

The infection of parasite-free silver carp by cohabitation with spore-releasing oligochaetes was successful in six out of seven fish (one fish died in the course of the three-month incubation period; it was negative for myxozoan plasmodia). Ninety-four days p.e., several dozen small plasmodia were detected on the gills of the infected fish (Fig. 2). The plasmodia were located in the epithelium of the gill lamellae and could easily be scraped off. In all fish, a massive infection was attained in some gill fila- ments where the majority of gill lamellae were affected. In the histological sections, several plasmodia containing developing myxospores were observed (Fig. 3). A complete parasitological dissection did not reveal the presence of other myxozoan parasites in any of the fish examined. The myxospores detected (Fig. 4) were morphologically similar to those of M. pavlovskii described by Akhmerov (1954). They exhibited the characteristic features like the unequally-sized polar capsules as well as the pronounced intercapsular process. There were slight but not significant differences in the range of myxospore measurements. The myxospore was slightly narrower and the large polar capsule was shorter in the present study (Table 2). The entire $18 \mathrm{~S}$ rDNA was successfully amplified and sequenced from two myxospore samples collected from different fish hosts. These DNA sequences were identical and found to be also congruent with the DNA sequence of the echinactinomyxon examined. They differed only in a single nucleotide $(0.13 \%)$ from that of $M$. pavlovskii available in GenBank (AF507973). The subsequent trial (10 months past the commencement of the study) to infect the laboratory oligochaete stock with these $M$. pavlovskii myxospores failed as no actinospores were detected in the water of the exposed worm container for 6 months upon regular checks.

\section{DISCUSSION}

In the present study, an echinactinomyxon-type actinospore was identified as the transmission stage of Myxobolus pavlovskii, a common parasite of bighead carp and silver carp in Hungary that has been studied repeatedly (Molnár 1971, 1979, 2002, Eszterbauer et al. 2002, Eszterbauer 2004). Several studies focused on the detection of the actinospore stages of myxozoan species occurring 
in Hungarian waters (El-Mansy 1998a, b, Eszterbauer et al. 2006). These surveys monitored the parasite fauna of local natural waters such as the river Tisza, Lake Balaton, and also the TEHAG fish farm from where our oligochaete stock originated. Although several actinospore types were detected in the course of these surveys, an echinactinomyxon-type has never been found. This is surprising because $M$. pavlovskii frequently occurs in fish from these localities; thus its actinospore stage should also be rather common. The echinactinomyxon was first detected in the TEHAG fish farm in the autumn of 2007. Because of the putative seasonality of the release of actinospores by oligochaetes (Yokoyama et al. 1993, El-Mansy et al. 1998a, Özer et al. 2002), it is likely that in the examined sampling area, $M$. pavlovskii echinactinomyxons are only released in the autumn. As previous surveys monitoring the myxozoan fauna were either completed in early autumn (Eszterbauer et al. 2006), or the samplings did not include ponds rearing silver carp (El-Mansy et al. 1998a), it is likely that the release of echinactinomyxons could not be recorded previously.

Our echinactinomyxon resembles the best the Echinactinomyxon 'C' described by Xiao and Desser (1998). However, Echinactinomyxon ' $\mathrm{C}$ ' has only 16 secondary cells and its invertebrate host is Limnodrilus hoffmeisteri. The dimensions of the spore body of the Echinactinomyxon 'D' by Xiao and Desser (1998) are also very similar to the echinactinomyxon of the present study. However, the caudal processes of Echinactinomyxon ' $D$ ' are longer (100 vs. $80.3 \mu \mathrm{m}$ in mean), and its invertebrate host is L. hoffmeisteri. Echinactinomyxon 'type 2' described by Negredo and Mulcahy (2001) resembles our echinactinomyxon in the length of the caudal processes, but it possesses a slightly longer spore body (19.6 vs. $15.2 \mu \mathrm{m}$ in mean), and its invertebrate host is Lumbriculus variegatus. The number of secondary cells of the latter echinactinomyxon is lower than in our echinactinomyxon (25 vs. 32). Both Echinactinomyxon radiatum (Janiszewska 1957) and the echinactinomyxon described in this study have 32 secondary cells, but E. radiatum is larger (length of the spore body: $25-30$ vs. $12.4-19 \mu \mathrm{m}$, length of the caudal processes: $100-125$ vs. $70.5-88.9 \mu \mathrm{m}$ ), and its invertebrate host is Tubifex tubifex. The Echinactinomyxon radiatum-like actinospore described by Xiao and Desser (1998) also differs in the length and width of the spore body (25 vs. 15.2 and 16.5 vs. $12.1 \mu \mathrm{m}$, respectively). Its caudal processes are longer (90 vs. $80.3 \mu \mathrm{m})$, and its invertebrate host is Tubifex tubifex. The other echinactinomyxon-type actinospores described so far differ greatly from the one found in this study (data not shown).

The 18S rDNA sequence of the echinactinomyxon of this study was found to be identical with that of a M. pavlovskii myxospore isolate previously published by Eszterbauer (2004). However, the 2,004 bp 'complete' $18 \mathrm{~S}$ rDNA sequence, a new entry in GenBank with an ap- proximately 500 bp longer DNA sequence (Acc. No. HM991164), supplies extended information for the genetic characterisation of this parasite. The myxospore samples, the partial 18S rDNA sequence of which was deposited to GenBank previously, originated from the same fish farm (TEHAG) as the oligochaetes releasing echinactinomyxons. However, these myxospore samples had been collected between 1998 and 2001, whereas the echinactinomyxon-type actinospores were detected in the autumn of 2007. The results of our cohabitation transmission experiments using silver carp fry and the echinactinomyxon-releasing oligochaetes strongly suggest that the echinactinomyxon at hand is the alternate spore stage of M. pavlovskii. Also the present histological findings correlate with the observations of Molnár (2002), who found that the developing cysts of $M$. pavlovskii are located in the stratified epithelium between the gill lamellae.

Effort was also undertaken to complete the life cycle of $M$. pavlovskii by infecting a parasite-free oligochaete culture with myxospores collected from the gills of the experimentally infected silver carp fry. Unfortunately, this attempt remained unsuccessful, possibly due to a changed composition of the worm culture which at the time of the trial might no longer be adequate for the development of the parasite. Beauchamp et al. (2006) reported that the species composition of an oligochaete culture may change over time. They found competitive interactions between susceptible and resistant Tubifex tubifex strains exposed to Myxobolus cerebralis; in this study the susceptible worm strain was displaced by the resistant one at the end of the trial. Furthermore, Shirakashi and El-Matbouli (2009) came to the conclusion that a myxozoan parasite has an adverse effect on the survival of the oligochaete host. They proved that Myxobolus cerebralis is capable of reducing the feeding activity and fecundity of the worms, thus the parasite has a notable influence on the composition of the oligochaete culture.

The conduction of experimental studies in order to characterize myxozoan life cycles entails many difficulties. For an infection trial, it is advantageous to work with parasite-free fish stocks and parasite-free oligochaete hosts, besides including negative controls. It is very time-consuming to rear and maintain these stocks under parasite-free conditions and it is known that infected oligochaetes may remain infected for more than a year (El-Matbouli and Hoffmann 1998, Hallett et al. 2005). Therefore, the best way to obtain parasite-free oligochaete stocks is to rear them from collected cocoons. But still, this is no guarantee that the susceptible worm species is able to reproduce under laboratory conditions at all. Myxozoans seem to be rather host-specific and their development is still only known in parts and unknown for most species. For most species, the invertebrate host is unknown, therefore choosing the right experimental setup (including the putative host range) for the exposure trials 
is crucial. This is why the in vivo development of only 35 species out of approximately 2,180 myxozoans has been followed experimentally hitherto. Thirty-two developmental cycles have been summarized in the review article by Lom and Dyková (2006), whereas the development of another three myxozoans has been described recently (Bartholomew et al. 2006, Køie et al. 2007, Székely et al. 2009).

Among Myxobolus spp., the most common actinospore type is the triactinomyxon (Lom and Dyková 2006), with only a few species in which another actinospore type occurs, like M. cultus (see Yokoyama et al. 1995), M. dispar (see Molnár et al. 1999) and M. lentisuturalis (see Caffara et al. 2009), which all produce raabeia-type actinospores. Our study is the first to report an echinactinomyxontype actinospore in a species of Myxobolus. Review articles (Kent et al. 2001, Lom and Dyková 2006) mention echinactinomyxon-type actinospores as the developmental stage of Sphaerospora truttae (see Özer and Wootten 2000) and Zschokkella sp. (see Yokoyama et al. 1991, 1993). However, S. truttae is a coelozoic species, which is phylogenetically distant from histozoic freshwater myxozoans such as M. pavlovskii. Furthermore, Holzer et al. (2004) reported that the $18 \mathrm{~S}$ rDNA of the echinactinomyxon-type actinospore, which was previously thought to be the transmission stage of $S$. truttae, was only $48.9 \%$ similar to the DNA sequence of the $S$. truttae myxospore. Kent et al. (2001) and Lom and Dyková (2006) referred to Zschokkella sp., a gall bladder parasite of Carassius auratus, as the myxospore counterpart of an echinactinomyxon found by Yokoyama et al. (1993). However, in the papers by Yokoyama et al. (1991, 1993), we failed to find any allusion that an echinactinomyxon is the actinospore type of Zschokkella sp. from goldfish.

The development of M. pavlovskii has formerly been studied by Ruidish et al. (1991). Their results disagree with ours as we found an echinactinomyxon in contrast to the hexactinomyxon-type actinospore they designated as the actinospore stage of $M$. pavlovskii. As in the study by Ruidish and colleagues $M$. pavlovskii myxospores originated from natural infections, it is possible that a contamination by another myxosporean species led to the different outcome. For example, Myxobolus drjagini, a common parasite of the silver carp in Europe, develops large white plasmodia in the subcutaneous tissue on the head of silver carp. In the course of fish dissection, this species might have contaminated the myxospore sample used by Ruidish et al. (1991). In our study, both the myxospore morphology and the histology of experimental infections confirmed that the species at hand was indeed M. pavlovskii. Contrary to the results of Ruidish et al. (1991), our findings were also verified by molecular methods. Therefore, we suspect that the results of Ruidish et al. (1991) may be due to contamination, whereas the true actinospore stage of M. pavlovskii is in fact the echinactinomyxon shown in this study.

Acknowledgements. The study was supported by the Hungarian Scientific Research Fund (OTKA K75873). The authors would like to thank Dr. Tarmo Timm for the morphological identification of the tubificid oligochaetes, and Krisztián Szabó for the fertilized silver carp spawn. Thanks are due to Dr. Dennis Kallert for the critical reading of the manuscript.

\section{REFERENCES}

Akhmerov A.K. 1954: [On closely related species of a new myxosporean genus.] Dokl. Akad. Nauk SSSR 97: 1101-1103. (In Russian.)

Barta J.R., Martin D.S., Liberator P.A., Dashkevicz M., Anderson J.W., Feighner S.D., Elbrecht A., Perkins-Barrow A., Jenkins M.C., Danforth H.D., Ruff M.D., ProfousJuchelka H. 1997: Phylogenetic relationships among eight Eimeria species infecting domestic fowl inferred using complete small subunit ribosomal DNA sequences. J. Parasitol. 83: 262-271.

Bartholomew J.L., Atkinson S.D., Hallett S.L. 2006: Involvement of Manayunkia speciosa (Annelida: Polychaeta: Sabellidae) in the life cycle of Parvicapsula minibicornis, a myxozoan parasite of Pacific salmon. J. Parasitol. 92: 742-748.

Beauchamp K.A., El-Matbouli M., Gay M., Georgiadis M.P., Nehring R.B., Hedrick R.P. 2006: The effect of cohabitation of Tubifex tubifex (Oligochaeta: Tubificidae) populations on infections to Myxobolus cerebralis (Myxozoa: Myxobolidae). J. Invertebr. Pathol. 91: 1-8.

Beauchamp K.A., Kathman R.D., McDowell T.S., Hedrick R.P. 2001: Molecular phylogeny of tubificid oligochaetes with special emphasis on Tubifex tubifex (Tubificidae). Mol. Phylogenet. Evol. 19: 216-224.
Caffara M., Raimondi E., Florio D., Marcer F., Quaglio F., Fioravanti M.L. 2009: The life cycle of Myxobolus lentisuturalis (Myxozoa: Myxobolidae), from goldfish (Carassius auratus auratus), involves a Raabeia-type actinospore. Folia Parasitol. 56: 6-12.

El-Mansy A., Székely C., Molnár K. 1998a: Studies on the occurrence of actinosporean stages of fish myxosporeans in a fish farm of Hungary, with the description of triactinomyxon, raabeia, aurantiactinomyxon and neoactinomyxon types. Acta Vet. Hung. 46: 259-284.

El-Mansy A., Székely C., Molnár K. 1998b: Studies on the occurrence of actinosporean stages of myxosporeans in Lake Balaton, Hungary, with the description of triactinomyxon, raabeia, and aurantiactinomyxon types. Acta Vet. Hung. 46: 437-450.

El-Matbouli M., Hoffmann R.W. 1998: Light and electron microscopic studies on the chronological development of Myxobolus cerebralis to the actinosporean stage in Tubifex tubifex. Int. J. Parasitol. 28: 195-217.

Eszterbauer E. 2004: Genetic relationship among gill-infecting Myxobolus species (Myxosporea) of cyprinids: molecular evidence of importance of tissue-specificity. Dis. Aquat. Org. 58: $35-40$. 
Eszterbauer E., Benkö M., Molnár K. 2002: Differentiation of morphologically very similar gill parasite Myxobolus species (Myxosporea) by restriction fragment length polymorphism method (PCR-RFLP). Magy. Állatorv. Lapja 124: 361-366. (In Hungarian with English summary.)

Eszterbauer E., Marton S., Rácz O.Z., Letenyei M., Molnár K. 2006: Morphological and genetic differences among actinosporean stages of fish-parasitic myxosporeans (Myxozoa): difficulties of species identification. Syst. Parasitol. 65: 97-114.

Eszterbauer E., Székely C. 2004: Molecular phylogeny of the kidney-parasitic Sphaerospora renicola from common carp (Cyprinus carpio) and Sphaerospora sp. from goldfish (Carassius auratus auratus). Acta Vet. Hung. 52: 469-478.

Hall T.A. 1999: BioEdit: a user-friendly biological sequence alignment editor and analysis program for Windows 95/98/NT. Nucl. Acids Symp. Ser. 41: 95-98.

Hallett S.L., Atkinson S.D., Erséus C., El-Matbouli M. 2005: Dissemination of triactinomyxons (Myxozoa) via oligochaetes used as live food for aquarium fishes. Dis. Aquat. Org. 65: 137-152.

Hallett S.L., Diamant A. 2001: Ultrastructure and smallsubunit ribosomal DNA sequence of Henneguya lesteri $\mathrm{n}$. sp. (Myxosporea), a parasite of sand whiting Sillago analis (Sillaginidae) from the coast of Queensland, Australia. Dis. Aquat. Org. 46: 197-212.

Hillis D.M., Dixon T. 1991: Ribosomal DNA: molecular evolution and phylogenetic inference. Quart. Rev. Biol. 66: 411-453.

Holzer A.S., Sommerville C., Wootten R. 2004: Molecular relationships and phylogeny in a community of myxosporeans and actinosporeans based on their $18 \mathrm{~S}$ rDNA sequences. Int. J. Parasitol. 34: 1099-1111.

Janiszewska J. 1957: Actinomyxidia II: New systematics, sexual cycle, description of new genera and species. Zool. Pol. 8: 3-34.

Kent M.L., Andree K.B., Bartholomew J.L., El-Matbouli M., Desser S.S., Delvin S.H., Feist, S.W., Hedrick R.P., Hoffmann R.W., Khattra J., Hallett S.L., Lester R.J.G., Longshaw M., Palenzuela O., Siddall M.E., Xiao C. 2001: Recent advances in our knowledge of Myxozoa. J. Eukaryot. Microbiol. 48: 395-413.

Køie M., Karlsbakk E., Nylund A. 2007: A new genus Gadimyxa with three new species (Myxozoa, Parvicapsulidae) parasitic in marine fish (Gadidae) and the two-host life cycle of Gadimyxa atlantica n. sp. J. Parasitol. 93: 1459-1467.

Loм J., Dyкоvé I. 2006: Myxozoan genera: definition and notes on taxonomy, life-cycle terminology and pathogenic species. Folia Parasitol. 53: 1-36.

MolnÁR K. 1971: Protozoan diseases of the fry of herbivorous fishes. Acta Vet. Hung. 21: 1-14.

MolnÁR K. 1979: Myxobolus pavlovskii (Achmerov, 1954) (Myxosporidia) infection in the silver carp and bighead. Acta Vet. Sci. Hung. 27: 207-216.

MolnÁR K. 2002: Site preference of myxosporeans in the gill. Dis. Aquat. Org. 48: 197-207.

Molnár K., El-Mansy A., Székely C., Baska F. 1999: Development of Myxobolus dispar (Myxosporea: Myxobolidae) in an oligochaete alternate host Tubifex tubifex. Folia Parasitol. 46: $15-21$.
Molnár K., Eszterbauer E., Székely C., Dán Á., Harrach B. 2002: Morphological and molecular biological studies on intramuscular Myxobolus spp. of cyprinid fish. J. Fish Dis. 25: 643-652.

Negredo C., Mulcahy M.F. 2001: Actinosporean infections in oligochaetes in a river system in southwest Ireland with descriptions of three new forms. Dis. Aquat. Org. 47: 67-77.

Özer A., Wootten R. 2000: The life cycle of Sphaerospora truttae (Myxozoa: Myxosporea) and some features of the biology of both the actinosporean and myxosporean stages. Dis. Aquat. Org. 40: 33-39.

ÖZer A., Wootten R., Shinn A.P. 2002: Infection prevalence, seasonality and host specificity of actinosporean types (Myxozoa) in an Atlantic salmon fish farm located in Northern Scotland. Folia Parasitol. 49: 263-268.

Ruidish S., El-Matbouli M., Hoffmann R.W. 1991: The role of tubificid worms as an intermediate host in the life cycle of Myxobolus pavlovskii (Akhmerov, 1954). Parasitol. Res. 77: 663-667.

Shirakashi S., El-Matbouli M. 2009: Myxobolus cerebralis (Myxozoa), the causative agent of whirling disease, reduces fecundity and feeding activity of Tubifex tubifex (Oligochaeta). Parasitology 136: 603-613.

Staden R. 1996: The Staden Sequence Analysis Package. Mol. Biotechnol. 5: 233-241.

Styer E.L., Harrison L.R., Burtle G.J. 1992: Six new species of actinomyxids from Dero digitata. International Workshop on Myxosporea, October 6-8, 1992, České Budějovice, Czech Republic (abstract only).

Székely C., Hallett S.L., Atrinson S.D., Molnár K. 2009: Complete life cycle of Myxobolus rotundus (Myxosporea: Myxobolidae), a gill myxozoan of common bream Abramis brama. Dis. Aquat. Org. 85: 147-155.

Whipps C.M., Adlard R.D., Bryant M.S., Lester R.J.G., Findlay V., Kent M.L. 2003: First report of three Kudoa species from eastern Australia: Kudoa thyrsites from mahi mahi (Coryphaena hippurus), Kudoa amamiensis and Kudoa minithyrsites $\mathrm{n}$. sp. from sweeper (Pempheris ypsilychnus). J. Eukaryot. Microbiol. 50: 215-219.

Xiao C., Desser S.S. 1998: Actinosporean stages of myxozoan parasites of oligochaetes from Lake Sasajewun, Algonquin Park, Ontario: new forms of echinactinomyxon, neoactinomyxon, aurantiactinomyxon, guyenotia, synactinomyxon, and antonactinomyxon. J. Parasitol. 84: 1010-1019.

Yokoyama H., Ogawa K., Wakabayashi H. 1991: A new collection method of actinosporeans -a probable infective stage of myxosporeans to fishes- from tubificids and experimental infection of goldfish with the actinosporean, Raabeia sp. Fish Pathol. 26: 133-138.

Yokoyama H., Ogawa K., Wakabayashi H. 1993: Some biological characteristics of actinosporeans from the oligochaete Branchiura sowerbyi. Dis. Aquat. Org. 17: 223-228.

Yokoyama H., Ogawa K., Wakabayashi H. 1995: Myxobolus cultus n. sp. (Myxosporea: Myxobolidae) in the goldfish Carassius auratus transformed from the actinosporean stage in the oligochaete Branchiura sowerbyi. J. Parasitol. 81: 446-451. 